\title{
Business simulations in financial management courses: Are they valuable to learners?
}

\author{
HP Wolmarans
}

\section{Department of Financial Management University of Pretoria}

\begin{abstract}
Business simulations are increasingly used to facilitate knowledge transfer in management education. Although such simulations have already been widely applied in other disciplines, this method of facilitating learning has not yet been used much in financial education. This article reports on three studies that examine the value added by this experiential learning method in a financial management course, as perceived by students. The reasons for students' experiencing this teaching method as positive are investigated. It would seem that financial education has much to gain from a wider application of business simulations.
\end{abstract}

\section{Key words}

Business simulations

Computer-assisted learning

Experiential learning

Teaching finance

\section{Introduction}

Given the rapid growth of computer technology, computer-based business simulations have considerable potential as an effective means to achieve educational objectives. Students tend to enjoy this type of learning opportunity, which exposes them to all four steps in the learning process, as identified by Kolb (1984:38), namely (1) concrete experience, (2) reflective observation, (3) abstract conceptualisation and (4) active experimentation. Although success in most, if not all computer-based business simulations is measured in financial terms (the profit made by simulated companies), it seems that this type of learning experience is not used in teaching financial concepts as often as in teaching other disciplines.

\subsection{The aim of this study}

This article seeks answers to the question of whether business simulations add significant value for students who are taking a financial management course. Do students in financial management regard a business simulation as a learning experience that is positive to a significant degree? Can simulations be used to enhance students' financial knowledge? What are the most important benefits that students experience when they participate in a 
simulation? What are the possible drawbacks? Answers to these questions may have important implications for financial education in future.

\subsection{The research approach}

This article reviews the results of three studies that were conducted to investigate the impact of using a business simulation in financial education. In the first study, a business simulation was used in an introductory course in finance for students studying for a Master's degree in Project Management (MPM). In the second study, the simulation was applied in two courses in finance for middle managers participating in a Management Development Programme (MDP). The third study involved running a simulation in two courses in finance for MBA students.

\section{Literature survey}

Computer-based business simulations offer considerable potential as a pedagogical tool in educational courses and training programmes (Gopinath \& Sawyer 1999:477). New technologies are transforming the business simulation industry and adding new capabilities and qualities (Summers 2004:208). When teachers and trainers use these simulations, they harness these capabilities and qualities, including the ever-increasing power of information technology to assist in the learning experience. Computers are excellent at quantifying a large number of interactions between critical variables, as well as at providing feedback to students rapidly. This rapid feedback often generates lively discussions in groups, allowing students to learn from one another. Thiagarajan (1998:35) suggests that computer-based business simulations for groups of participants may prove to be one of the main contributions that this technology makes to education. Wolmarans (2000:1) has also found that business simulations offer a number of advantages and satisfy some of the requirements of the South African Qualifications Authorities (SAQA).

Business simulations are also known in the subject literature as "simulation games", or "business games". The focus falls on the simu lation of business activities under competitive conditions. However, because some managers frown on the term "games" and say that they "work and don't play" (Fripp 1993:33), the term "business simulation" is preferred. In most of these computer-based business simulations, groups of participants manage their simulated companies under competitive conditions, and the aim of the simulation is for each group to try to be more successful than its competitors.

Participants in training programmes usually receive business simulations enthusiastically, because they can participate actively in the learning process (Brooks 1996:2). Because the students are required to play an active role, they can apply knowledge gained from lectures, case studies or other instructional formats practically. In addition, the success of a simulated firm is directly related to the effort and knowledge of the students who act as the "company directors". This type of learning opportunity gives participants the largest possible amount of exposure to all four steps in the learning process, as identified by Kolb (1984:38).

Business simulations provide a teaching method that typically yields (1) more hands-on experience, (2) a higher level of excitement, (3) a higher noise level (and yet a lower incidence of problems), and (4) more commitment, than traditional methods of teaching (McLure 1997:3). People learn more when they are enjoying themselves. This is not just true of children. It is also true of executives and managers - of everyone (Elgood 1997:5). Rao (1995:44) agrees that learning is more effective when it is combined with enjoyable 
activities. The material that is mastered in such a way is also remembered longer. Washbush and Gosen (2001:281) investigated a series of exploratory studies dealing with learning in total enterprise simulations and found that this type of simulation offers considerable potential for student learning in various disciplines.

Anderson and Lawton (1992b:326) report that students perceived a computer-based management simulation exercise to be superior to case discussions in learning skills in a business policy course. Hendrikz (1991:13) found that students in a marketing course perceived simulations to be a significantly more effective method of transferring managerial competence than self-study, case studies and lectures. Joannides and Oldenboom (1999:38) agree that business simulations can be a highly effective educational technique. Faria (1998:304) reports that users of computer simulations rate them far more highly as effective teaching methods than either lectures or case studies. When a business simulation was used in the introductory week of an executive MBA course, Gooding and Keys (1990:54) even found that participants became so committed to the simulation that they had to be actively encouraged to move away from simulation activities and back into lectures and case discussion sessions.

Although success is measured in financial terms in most computer-based business simulations (Walters, Coalter \& Rasheed 1997; Wolfe \& Rogé 1997; Vaidyanathan \& Rochford 1998; Lee 1999; Tompson \& Dass 2000), it is noteworthy that this type of experiential learning activity has not been used nearly as often in financial management education as in education in other disciplines. In a study to determine the extent to which simulations were used in various disciplines, Faria (1998:299) found that only 39\% of the American Assembly of Collegiate Schools of Business (AACSB) member schools used simulations as part of their finance courses. This percentage was lower than the comparable figures for general management (45\%), marketing (63\%) and business policy (66\%).

A simulation is one example of experiential learning. Gentry (1990:20) defines it as "participative, interactive and applied", or, to put it differently, as "learning by doing". Other examples of experiential learning that have been successfully used in financial education are live case studies, community service, and practical experience as vacation workers (Dahlquist 1998:76). Because computer-based simulations can be run quickly, students are afforded more opportunities to practise their managerial skills through the decisions they make. White, Helms and Parker (1990:33) agree that a computer-based business simulation can thus be a useful and satisfying way for students to acquire financial knowledge.

Computer-based simulations have been used in financial education for a number of different reasons. Greenlaw, Frey and Vernon (1979:5) reported positive results over many years of using a computer-based finance-focused simulation. When a computer-based portfolio strategy simulation was used in a graduate investments course, Burns and Burns (1982:81) found that $87 \%$ of the students attending the course felt that they had learnt much more during the course, due to the simulation, than they would have learnt otherwise. Rice and Haslem (1981:91) found that financial management skills could be greatly enhanced by an educational programme including computer-based simulation cases. Pampallis (1984) and Tredoux (1985) also agree that a simulation game can be a valuable teaching aid in financial education.

Singleton (1986:79) found a computer-based simulation to be useful in introducing the basics of options trading. In investment management, Tessema (1989:33) used a stock market game which simulates investments on the New York Stock Exchange, together with instructions consistent with current practices. This was found to be an effective approach to 
involve students in making investment decisions and to enable them to put their new-found theoretical skills into practice. Elan and Sanderson (1991:11) also found investment simulations effective in capturing the multitude of components contained in portfolio management.

Angel (1994:61) found that a simulated market in which shares are bought and sold by the students to be an enjoyable way to introduce them to the workings of real financial markets. Smith (1996:76) used Internet data bases to provide simulated exposure to portfolio management to students in an introductory finance course. Cooper and Grinder (1997:95) introduced option-pricing theory using a classroom simulation and found the simplicity of the simulation and the excitement generated by fellow students to be contagious. Hogan and Kish (1999:83) found that the investigation of simulated portfolios containing stocks and bonds was valuable in explaining the trade-offs between risk and return in an introductory investment course. More recently, a computer-based simulation assisted with decis ion-making in a dynamic environment as part of a course in investment management (Brozik \& Zapalska 2002:242). Furthermore, Wenzler (2005:75) has reported on a simulation aimed at maximizing financial performance through different asset managing strategies, while still providing a better-than-required service. From these studies the important role that simulations may play in finance and investment education is evident.

Most business simulations use financial variables to determine the success of participating teams. Examples of these are increased profitability, larger net assets, greater cash flows and higher share prices. Other examples are return on investment, return on equity and net asset value (Anderson \& Lawton 1992a:490). Indeed, even in business simulations that are primarily focused on enhancing strategic skills or marketing skills, the term "team performance" is usually used as a euphemism for cumulative profits over the time periods when the game was played (Teach 1990:12).

However, some reservations have been expressed concerning a system that uses only financial performance as a measure of learning. Some of these include the fact that a participating team could "fall into a profitable strategy and stay there" without planning; that a business simulation cannot account for all the variables encountered in real life; or that the performance of losing teams may perhaps not be a true reflection of the knowledge of the individuals in those teams. Students can be successful even if they know little about the rules and the underlying business theories driving the simulations (Wolfe \& Luethge 2003:69). In spite of these reservations, it still seems to be common practice for instructors to use relative financial performance as a key measure of success in any competitive simulation exercise.

Despite the information on simulations, a fairly extensive literature study did not uncover a study describing students' experiences of how successful a simulation is in conveying critical concepts in South African finance education. This could be an area in which the innovative concept of business simulation could add much value.

\section{The business simulation}

The aim of using a business simulation in an introductory finance course would be to enable participants to experience first-hand what the implications of different decisions are for the profitability of a company. It is also important that participants acquire a holistic overview of the process of doing business, in order to realise that all processes have to be aligned in an optimal system. 
The simulation used was PROSPEX (Macey 1997). This is a whole enterprise simulation of middling complexity. It simulates the flow of value through a manufacturing company. This simulation is suitable for enhancing the financial skills of adult learners. It ran on a laptop computer, with a printer attached, in order to print the results of each round of decisions.

The participants present formed teams consisting of six to eight people each. Each team managed a company competing with other companies in a market with two products. This structure where teams compete is called a "tournament" and has been found to be highly effective when teaching business skills with a total enterprise simulation (Thavikulwat \& Pillutla 2004:5). Each team provided values for 11 variables for each time period (representing two months of real time). The variables ranged from the amounts of raw materials, labour hours and bank loans required by the manufacturing company to the prices at which two manufactured products are sold, the amount spent on advertising and the consultants' reports required on the current competitive situation. Three pages of output per period include detail on the income statement and the balance sheet. Each team aimed to have the mo st profitable company at the end of the simulation.

\section{The procedure}

The procedure followed was suggested by Fripp (1993:101) and it is set out in Figure 1. The students were given a short introduction to the simulation, with an explanation of all the variables, their relationships and the way they interact financially. They were also each given a copy of the participants' manual (only five pages) to refer to when they had to decide on the input-variables. This way of introducing a simulation has been found to be very effective under time pressure (Snow, Gehlen \& Green 2002:526)

\section{Figure 1 The structure of a typical computer-based business simulation}

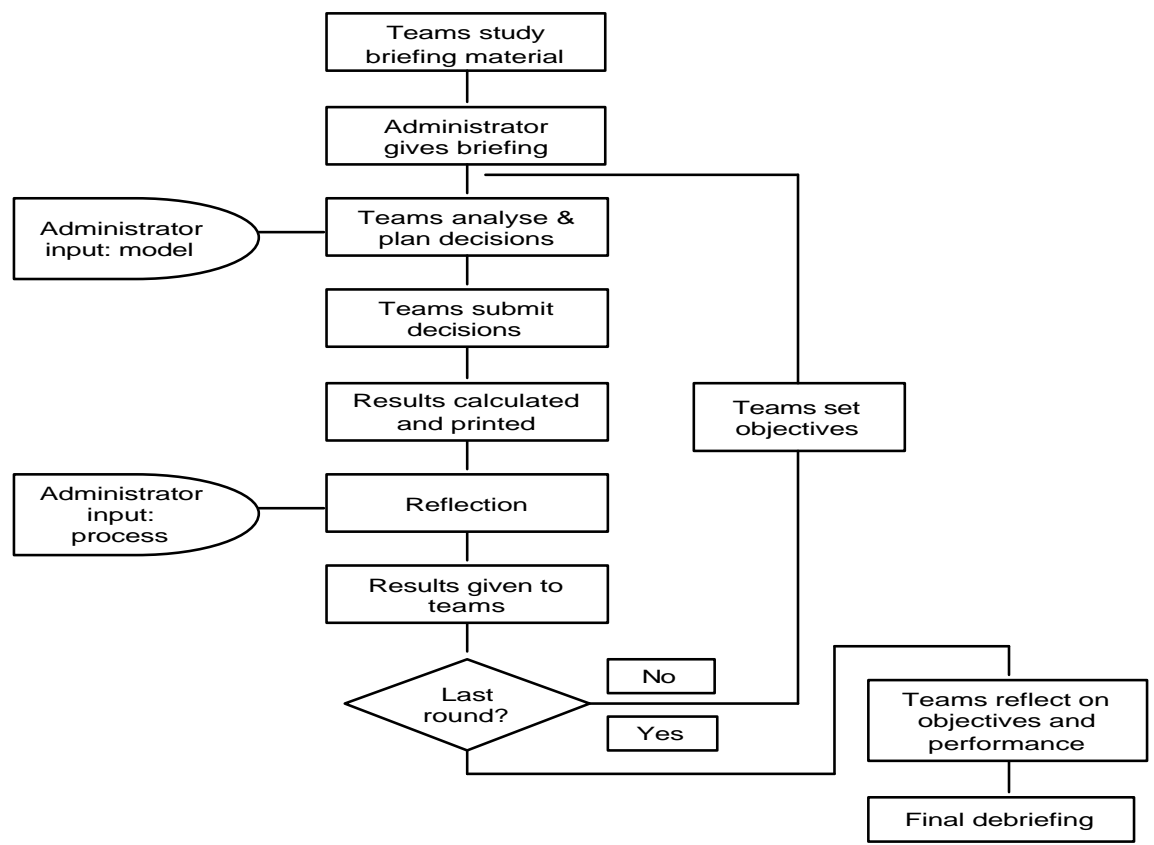

Source: Fripp (1993:101) 
Each team represented the "board of directors" of their respective company. Regular "board meetings" were held to decide on the values for the input-variables. The business simulation was integrated with the course in finance, in the sense that frequent reference was made to where participants could find, for instance, the elements of the income statement on the computer printout for their companies. Financial concepts such as analysing statements or the difference between fixed and variable cost were also explained with reference to the simulated companies. The participants were often requested to use parts of their tea times and lunch times to complete the input forms, in line with Nicholson's (1997:438) contention that good business simulations should put participants under at least some time pressure, similarto real decision-making.

After the simulation had ended and the winning team had been congratulated, the participants were requested to provide written feedback on how they had experienced the simulation. Petranek (2000:108) argues that students learn mo re from a written debriefing than from a mere oral debriefing. It was emphasised that debriefing is an important part of the learning process because it allows students to make a connection between the experience they had gained from the simulation and experiences in real-life situations, as postulated by Peters and Vissers (2004:70).

The students were requested to rate the learning they had experienced during the simulation game on a scale of 1 ("very little") to 10 ("quite a lot"). They also had to rate their learning experience during the average lecture, as well as the average case study they had encountered up to that point. The students were requested to list the three main benefits that they had experienced in the simulation. They were asked to respond to the following questions: Had the simulation added value to their financial knowledge? Should it be used in future? The students could also comment on their experience of the simulation, including any possible drawbacks.

The results were analysed using the SAS (Statistical Analysis Systems) on the mainframe of the University of Pretoria. A Waller-Duncan k-ratio t-test was performed in the PROC GLM procedure (SAS Institute 1985:487) to determine whether the respondents rated the simulation, lectures and cases in a similar manner or not. Means with the same letter under "Grouping" in the output to this procedure are not significantly different, which could assist the researcher in deciding whether the participants had rated the simulation significantly higher than either cases or lectures (see Tables 1, 4 and 7).

\section{The first study}

\subsection{The sample}

The business simulation was used during a 24-hour, three-day course in finance for students doing a Master's degree in Project Management (MPM). Finance is a compulsory module in this programme. All these students had at least a four-year degree in engineering (BEng) or a three-year degree in science (BSc). None of them had had previous academic exposure to finance. Their median age was 30 years, with a range from 26 to 44 years. Of the 38 students, only four indicated that they had had previous exposure to simulations as a learning experience, all in an operational (production) environment. All the students indicated that they had had exposure to lectures and case studies in previous studies, and it was therefore assumed that they were able to compare their experience of the business simulation with these two methods of conveying information. 


\subsection{The results}

The rating of learning opportunities by the MPM students is given in Table 1. The amount of learning that the students experienced during the simulation was rated on a scale of 1 to 10, with 10 representing the most learning experienced. The average lecture and average case study were rated on a similar scale for comparison purposes. Groupings with the same letter are not significantly different.

Table 1 Rating of learning opportunities by MPM students $(n=38)$

\begin{tabular}{|l|c|c|c|}
\hline Learning opportunity & Average & Std.dev. & Grouping \\
\hline Business simulation & 8.63 & 1.63 & $\mathrm{~A}$ \\
\hline Average lecture & 7.18 & 1.56 & $\mathrm{~B}$ \\
\hline Average case study & 7.16 & 1.46 & $\mathrm{~B}$ \\
\hline
\end{tabular}

From Table 1, it is clear that these students experienced significantly more learning during the simulation game than during both the average case study and average lecture to which they had had prior exposure. They were also requested to rate, on a 10-point scale $(1=$ "least/no", $10=$ "most/yes"), firstly, the contribution of the simulation game to their knowledge of finance, and secondly, whether this type of experiential learning activity should be used again in future. The results are set out in Table 2. Both average ratings differ significantly from $5.5(\mathrm{p}<0.01)$, which was the mid-range of possible ratings. The results confirm that the simulation game contributed significantly to their knowledge, and the students were of the opinion that this type of experiential learning should definitely be used again in future.

Table 2 Average response of MPM students $(n=38)$

\begin{tabular}{|l|c|c|c|}
\hline Question & $\begin{array}{c}\text { Average } \\
\text { response }\end{array}$ & Std.dev. & Significance \\
\hline Contribution of simulation to financial knowledge & 8.79 & 1.33 & $\mathrm{p}<0.01$ \\
\hline Should the simulation be used in future? & 9.42 & 1.13 & $\mathrm{p}<0.01$ \\
\hline
\end{tabular}

The students were requested to provide and rank the three most important benefits that they had experienced during the business simulation. The results of the answers to this openended ques tion are summarised in Table 3, where only the five most important benefits are listed.

Table 3 The ranking of benefits by the MPM students $(n=38)$

\begin{tabular}{|ll|c|c|c|c|c|}
\hline Benefit & 1st & 2nd & 3rd & Total & $\%$ \\
\hline 1 & A holistic financial overview of a company & 12 & 8 & 4 & 24 & 63 \\
\hline 2 & Teamwork and learning in groups & 8 & 6 & 7 & 21 & 55 \\
\hline 3 & Improved decision-making & 7 & 6 & 5 & 18 & 47 \\
\hline 4 & Understanding financial statements & 5 & 9 & 8 & 22 & 58 \\
\hline 5 & Thinking in terms of profitability & 3 & 4 & 3 & 10 & 26 \\
\hline
\end{tabular}

From Table 3 it is clear that experiencing the simulation helped these students obtain a holistic financial overview of a company. They also experienced better decision-making through teamwork and learning in groups. The exercise helped them to understand financial statements better; and they were better able to think in terms of profitability.

The comments were generally favourable. Those students who gave negative feedback mostly felt that the time allocated for the simulation was too short.

Meditari Accountancy Research Vol. 13 No. 12005 : 121-133 


\section{The second study}

\subsection{The sample}

In a second study, two groups of middle managers on a Management Development Programme (MDP) were exposed to the business simulation during the 20-hour finance module (spread over three days) of their course. Up to that point, the students had already had exposure to $40 \%$ of the ten disciplines in the course, where mainly lectures and case studies were used as learning opportunities. These students could thus compare their experience of the simulation with the learning experienced during the typical lecture and case study. There is no reason to believe that the two groups experienced the simulation or previous lectures and cases differently.

There were 62 students in total in the two courses, ranging in age from 34 to 50 years, with a median age of 38 years. A total of $80 \%$ of them did not have any tertiary education, with half of the remainder $(10 \%)$ qualified in non-commercial disciplines. Thus, while only about $10 \%$ had had some exposure to formal commercial education, which could affect their group's performance, none of these students indicated that they had had previous experience of a business simulation.

\subsection{The results}

The rating of learning opportunities by the MDP students is given in Table 4. Groupings with the same letter are not significantly different. From this rating, it is evident that these students experienced significantly more learning during the simulation, as compared with the learning during an average lecture or case study.

Table 4 Rating of learning opportunities by the MDP students $(n=62)$

\begin{tabular}{|l|c|c|c|}
\hline Learning opportunity & Average & Std.dev. & Grouping \\
\hline Business simulation & 8.26 & 1.29 & $\mathrm{~A}$ \\
\hline Average case study & 7.40 & 1.28 & $\mathrm{~B}$ \\
\hline Average lecture & 7.18 & 1.47 & $\mathrm{~B}$ \\
\hline
\end{tabular}

As in the first study, the students were requested to rate the contribution of the simulation to their knowledge of finance and whether this type of experiential learning activity should be used again in future. The results are given in Table 5.

Table 5 Average response of MDP students ( $n=62)$

\begin{tabular}{|l|c|c|c|}
\hline Question & $\begin{array}{c}\text { Average } \\
\text { response }\end{array}$ & Std.dev. & Significance \\
\hline Contribution of simulation to financial knowledge & 8.58 & 1.41 & $\mathrm{p}<0.01$ \\
\hline Should the simulation be used in future? & 9.11 & 1.09 & $\mathrm{p}<0.01$ \\
\hline
\end{tabular}

In Table 5 both average ratings differ significantly from 5.5 , the mid-range of possible ratings. This confirms that the simulation game contributed significantly to the students' financial knowledge. They are of the opinion that this type of experiential learning should definitely be used in future.

The students were requested to rank the three most important benefits that they experienced during the business simulation. The results in respect of the answers to this question are summarised in Table 6, where only the five most important benefits are listed. 
Table 6 The ranking of benefits by MDP delegates $(n=62)$

\begin{tabular}{|l|c|c|c|c|c|}
\hline Benefit & 1st & 2nd & 3rd & Total & $\%$ \\
\hline 1 Improved decision-making & 14 & 8 & 5 & 27 & 44 \\
\hline 2 A holistic financial overview of a company & 13 & 8 & 4 & 25 & 40 \\
\hline 3 Teamwork and learning in groups & 7 & 9 & 8 & 24 & 39 \\
\hline 4 Interaction between critical variables & 7 & 5 & 3 & 15 & 24 \\
\hline 5 Understanding financial statements & 5 & 9 & 8 & 22 & 35 \\
\hline
\end{tabular}

From Table 6 it is clear that the students experienced improved decision-making as the most important benefit, followed by a holistic financial overview of a company. Teamwork and learning in groups was important; they achieved a better grasp of the interaction between critical variables; and they gained a better understanding of financial statements. The fact that the percentages in the last column of Table 6 are lower than those in Table 3 is mostly due to the fact that not all these students listed the benefits that they had experienced.

Comments on the simulation were generally favourable. Some delegates found the time allocated to the simulation too short. Others found that if they made mistakes in early runs, it could be too late to rectify these errors by the time that they knew more about the critical success factors in the simulation.

\section{The third study}

\subsection{The sample}

In a third study, the business simulation was applied during a first course in finance for two groups of MBA students. One of these groups (after hours) attended weekly evening classes over a semester, while the other group's (modular) classes were spread over two separate two-week periods with a two-month break in between. In the total of nearly 30 hours lecturing time, rather more financial concepts were covered than with the groups in the previous two studies, and there was less opportunity to exert time pressure on students, due to the extended period of their exposure to finance. The results of the simulation were included as $20 \%$ of the MBA students' semester mark, whereas it did not count towards participants' progress marks in the first two studies. Nevertheless, if the assumption is made that these differences in the conditions under which participants experienced the simulation have not had a major impact, the results of this study could be compared to those of the first two studies.

All these MBA students had at least a three-year degree, and about $30 \%$ had studied commerce. About $20 \%$ of the students had had previous exposure to a simulation, but not in a finance course. The students' ages ranged between 25 and 46, with a median age of 32 .

\subsection{The results}

When the MBA students were requested to rate their learning during the simulation versus learning in an average lecture and an average case study discussion as they experienced it up to that point, they gave the answers set out in Table 7 . The average rating of the simulation, although significantly better than that of the average lecture and case study, is somewhat lower than the rating received in the first two studies. This could be due to the possibility that these students experienced less euphoria, that they were exposed for longer, or that the results of the simulation counted towards the semester mark. 
Table 7 Rating of learning opportunities by MBA students (n=66)

\begin{tabular}{|l|c|c|c|}
\hline Learning opportunity & Average & Std.dev. & Grouping \\
\hline Business simulation & 8.19 & 1.49 & $\mathrm{~A}$ \\
\hline Average lecture & 7.16 & 1.35 & $\mathrm{~B}$ \\
\hline Average case study & 7.05 & 1.27 & $\mathrm{~B}$ \\
\hline
\end{tabular}

Table 8 Average response of MBA students (n=66)

\begin{tabular}{|l|c|c|c|}
\hline Question & $\begin{array}{c}\text { Average } \\
\text { response }\end{array}$ & Std.dev. & Significance \\
\hline Contribution of simulation to financial knowledge & 7.81 & 1.29 & $\mathrm{p}<0.01$ \\
\hline Should the simulation be used in future? & 8.51 & 1.35 & $\mathrm{p}<0.01$ \\
\hline
\end{tabular}

The simulation contributed significantly towards MBA students' knowledge of finance (Table 8) and the students agreed that it should definitely be used in similar courses in future. The somewhat lower ratings of Table 8 could once again be due to the possibility that these students experienced less euphoria.

Table 9 The ranking of benefits by MBA students ( $n=66$ )

\begin{tabular}{|l|c|c|c|c|c|}
\hline Benefit & 1st & 2nd & 3rd & Total & $\%$ \\
\hline Group discussions and exchanging ideas & 23 & 18 & 9 & 50 & 76 \\
\hline Financial overview of managing a company & 11 & 7 & 11 & 29 & 44 \\
\hline Understanding financial statements & 5 & 6 & 8 & 19 & 29 \\
\hline Linking theory to practice & 4 & 5 & 6 & 15 & 23 \\
\hline Better decision-making & 3 & 4 & 4 & 11 & 17 \\
\hline
\end{tabular}

The ranking of benefits experienced while participating in the simulation is eported in Table 9. These students regarded group discussions and exchanging ideas as the most important benefit, followed by the benefit of having a better financial overview of a company. The students understood financial statements better and were able to link theory to practice. What is perhaps surprising is the relatively low ranking of better decisionmaking, compared to the results of the first two studies.

The comments were mainly positive and only a few students experienced drawbacks. Some students felt that the simulation was not flexible enough; some noted that group dynamics had to be sorted out before more effective decision-making could occur; and others initially made mistakes because they did not understand the relationships between the critical variables.

\section{Summary and conclusion}

In the introduction to this article, the question was posed whether students in financial management regard a business simulation as a significant positive learning experience. The results of Tables 1, 4 and 7 confirm that the participants in three studies experienced a business simulation as a significantly more positive learning experience than either the average lecture or the average case study.

The second question asked was whether simulations could be used to enhance students' financial knowledge. The results of Tables 2,5 and 8 prove that participants experienced a significantly positive impact on their financial knowledge. They also agree that simulations should be used in future finance courses.

The third question asked was what the most important benefits that students experience when they participate in a simulation were. The students had a positive experience of 
teamwork and learning in groups; they obtained a holistic financial overview of a company; they experienced better decision-making; they understood financial statements and the interaction between critical variables better; they linked theory to practice; and they learned to think in terms of profitability. A few students found the time allocated to the simulation too short. The dynamics in some groups initially interfered with effective decision-making. Initial mistakes could also not be rectified later in the simulation.

The conclusion can be drawn that students had a significantly positive experience of these business simulations. It seems that total enterprise business simulations have a definite role to play in financial management education. Finance lecturers could take this into account when planning future value-adding opportunities.

\section{Areas for further study}

Joannides and Oldenboom (1999:38) determined the extent to which business simulations were used in marketing education in South Africa in 1999. However, no such study has been done with regard to the use of simulations in financial education. Research is thus still needed to determine how widely business simulations are used in South African financial education. What are the main obstacles that finance educators experience when they use simulations and how can these obstacles be overcome? Lastly, how can business simulations be used on a wider scale to enhance students' understanding of financial concepts while still creating a favourable learning experience? Financial education may have much to gain from a wider application of business simulations.

\section{Bibliography}

Anderson, P.H. \& Lawton, L. 1992a. A survey of methods used for evaluating student performance on business simulations. Simulation \& Gaming, 23(3):490-498.

Anderson, P.H. \& Lawton, L. 1992b. The relationship between financial performance and other measures of learning on a simulation exercise. Simulation \& Gaming, 23(3): 326-340.

Angel, J.J. 1994. The Broker Game: an enjoyable way to introduce students to financial markets. Financial Practice and Education, 4(1):61-64.

Brooks, L.D. 1996. PC FinGame: The Financial Management Decision Game. London: Irwin.

Brozik, D. \& Zapalska, A. 2002. The PORTFOLIO GAME: Decision making in a dynamic environment. Simulation \& Gaming, 33(2):242-258.

Burns, W. \& Burns, M. 1982. The use of a portfolio management simulation as a learning device. Journal of Financial Education, 11, Fall:79-82.

Cooper, D.W. \& Grinder, B. 1997. Introducing options pricing theory with a classroom game. Financial Practice and Education, 7(1):95-102.

Dahlquist, J.R. 1998. Using service-learning in finance: a project example. Journal of Financial Education, 24, Spring:76-80.

Elan, D. \& Sanderson, G.R. 1991. Investment games: a modular approach. Journal of Financial Education, 20, November:11-16. 
Elgood, C. 1997. Handbook of management games and simulations. $6^{\text {th }}$ edition. Aldershot: Gower.

Faria, A.J. 1998. Business simulation games: current usage levels - an update. Simulation \& Gaming, 29(3):295-308.

Fripp, J. 1993. Learning through simulations: a guide to the design and use of simulations in business and education. London: McGraw-Hill.

Garris, R., Ahlers, R. \& Driskell, J.E. 2002. Games, motivation, and learning: a research and practice model. Simulation \& Gaming, 33(4):441-467.

Gentry, J.W. 1990. Guide to business gaming and experiential learning. London: Kogan Page.

Gooding, C. \& Keys, J.B. 1990. Introducing executive MBA programmes with management games. Journal of Management Development, 9(2):53-60.

Gopinath, C. \& Sawyer, J.E. 1999. Exploring the learning from an enterprise simulation. Journal of Management Development, 18(5):477-489.

Greenlaw, P.S., Frey, M.W. \& Vernon, I.R. 1979. FINANSIM: a Financial Management Simulation. New York: West.

Hendrikz, J.D.S. 1991. The effective use of simulations in management education. South African Journal of Economic and Management Sciences, 6:1-16.

Hogan, K.M. \& Kish, R.J. 1999. Stocks, bonds, or both: an exercise in risk/return tradeoffs. Simulation \& Gaming, 30(1):83-89.

Joannides, D. \& Oldenboom, N. 1999. The role of marketing simulation games in tertiary education: a South African perspective. South African Journal of Higher Education, 13(1):38-45.

Kolb, D.A. 1984. Organizational Psychology: an experiential approach to organizational behaviour. Englewood Cliffs, New Jersey: Prentice Hall.

Lee, J. 1999. Effectiveness of computer-based instructional simulation: a meta analysis International Journal of Instructional Media, 26(1):71-84.

Macey, H. 1997. PROSPEX: a business simulation. Norwich: Harrison Macey.

McLure, J. 1997. Games and simu lations: a modest proposal. Science Activities, 34(2):3-5.

Nicholson, A. 1997. Bringing management reality into the classroom: the development of interactive learning. Journal of Management Development, 16(6):438-451.

Pampallis, A. 1984. A simple financial theory management simulation game: a teaching aid in finance. Unpublished MBL dissertation, University of South Africa, Pretoria.

Peters, V.A.M. \& Vissers, G.A.N. 2004. A simple classification model for debriefing simulation games. Simulation \& Gaming, 35(1):70-84.

Petranek, C.F. 2000. Written debriefing: The next vital step in learning with simulations. Simulation \& Gaming, 31(1):108-118.

Rao, S. 1995. Putting fun back into learning. Training, 32(8):44-48.

Rice, J.G. \& Haslem, J.A. 1981. The use of computer-based simulation cases for educational programmes in financial institutions. Journal of Financial Education, 10, Fall:91-108.

SAS Institute. 1985. SAS User's Guide. $5^{\text {th }}$ edition. North Carolina: Cary Publishing. 
Singleton, J.C. 1986. A stock options game. Journal of Financial Education, 15, Fall:7985.

Smith, S.D. 1996. Using EDGAR on the Internet to teach finance and business courses. Journal of Financial Education, 22, Fall:76-78.

Snow, S.C., Gehlen, F.L. \& Green, J.C. 2002. Different ways to introduce a business simulation: the effect on student performance. Simulation \& Gaming, 33(4):526-532.

Summers, G.J. 2004. Today's business simulation industry. Simulation \& Gaming, 35(2):208-241.

Teach, R.D. 1990. Profits: the false prophet in business gaming. Simulation \& Gaming, 21(1):12-26.

Tessema, A. 1989. A stock market game in teaching investments. Journal of Financial Education, 18, Fall:33-37.

Thavikulwat, P. \& Pillutla, S. 2004. The tournament concept in assessment. Simulation \& Gaming, 35(1):5-28.

Thiagarajan, S. 1998. The myths and realities of simulations in performance technology. Educational Technology, 38(5):35-41.

Tompson, G.H. \& Dass, P. 2000. Improving students' self-efficacy in strategic management: the relative impact of cases and simulations. Simulation \& Gaming, 31(1):22-41.

Tredoux, N. 1985. The development and programming of a computerised situation simulation for managers. Pretoria: Human Sciences Research Council.

Vaidyanathan, R. \& Rochford, L. 1998. An exploratory investigation of comp uter simulations, student preferences and performance. Journal of Education for Business, 73(3):144-149.

Walters, B.A., Coalter, T.M. \& Rasheed, A.M.A. 1997. Simulation games in business policy courses: is there value for students? Journal of Education for Business, 72(3):170-174.

Washbush, J. \& Gosen, J. 2001. An exploration of game-derived learning in total enterprise simulations. Simulation \& Gaming, 32(3):281-296.

Wenzler, I. 2005. Development of an asset management strategy for a network utility company: lessons from a dynamic business simulation approach. Simulation \& Gaming, 36(1):75-90.

White, C.S., Helms, M.M. \& Parker, B. 1990. Simulations versus cases: impact on the interpretation of financial statements. Journal of Financial Education, 19, Fall:33-36.

Wolfe, J. \& Luethge, D.J. 2003. The impact of involvement on performance in business simulations: an examination of Goosen's "Know little" decision-making thesis. Journal of Education for Business, 79(2):69-75.

Wolfe, J. \& Rogé, J. 1997. Computeris ed general management games: the effectiveness of business games in strategic management course work. Simulation \& Gaming, 28(4):423-441.

Wolmarans, H.P. 2000. Simulation games in management education - an educational technique with great potential? Management Dynamics, 9(4):1-33. 